\title{
EDUCATION IN ANCIENT INDONESIA CULTURE (700-1700)
}

\author{
Aminuddin Kasidi ${ }^{1}$
}

\begin{abstract}
Within 1359-1364, Hayam Wuruk did a quest monitoring Majapahit, either to the east side, or the west side. From the many objects he visited, in addition to visiting authorities and local villagers, he also visited religious sacred places. Prapanca, who worked as Dharmadyaksa ring Kasogatan was one of the higher authorities in the kingdom who followed him (Pigeaude, 1963, IV, 150-153). The king's quest was also followed by many authorities, and they were certainly intellectual prominent figures in their era. The position of saptopapati, for instance, was occupied by those who were entitled to as pangei or sanget. The term was derived from the root words of ( $V$ pgat) meaning: putus (Jw) mastery (Van Naerssen, 1933: 239-258). Furthermore, the terms of pgat is also defined by Van Nseassen as notable (Naerssen, 1933: 239-258). Within various epigraphs, authority titled with pamget or samget was under the third position of kingdom higher authority: rakryan katrini, namely rakrayan kartini (three higher authority), rakrayan mamantri I Hino, Rakryan I halu, Rakryan I Siikan. Within Nagarakratagama, pupuh 68, the second syair noted :" ... wanten bodda Mahayana pgat/rin tantra yogiswara ... was an expert (Jw. Mumpuni) of Buddha mahyana's lesson on Tantra and Yoga ..." (Pigeadu, 1963: 52). The terms refer to educated people who have comprehensive and mastery knowledge, so that they can take a decision based on their expertise independently, either in the field of science or governmental problems. Accordingly, if they master their knowledge (Jw. Putusing ngilmu), they will have the authority to make decision towards a problem whenever they are needed. The question is: what kind of knowledge, how can they attain it, and where they learn it? In many sources it was known that one kind of education spread within the age was mandala. During his quest, Hayam Wuruk, for example visited mandala segara. The term mandaleng (mandala - ing) was also found in Serat Pararaton. This article focuses on studying education in ancient Indonesia.
\end{abstract}

Key words : mandala, ancient Indonesia, education

\section{Introduction}

Djumhur and Danasaputra in their book entitled Sejarah Pendidikan state that every generation inherits culture through education as time goes by (Djumhur \& Danasaputra, 1959: 1). Education as an institution of the transfer of cultural development can be formal and informal as well as communal and individual (Hariani Santiko, 1990: 156-171). Education is a medium in achieving

${ }^{1}$ Prof. Dr. Aminuddin Kasidi, lecturer at the Department of History Education, Universitas Negeri Surabaya. His article has been reviewed by Prof. Dr. Said Hamid Hasan, MA. (Universitas Pendidikan Indonesia) and Prof. Dr Dadang Supardan (Universitas Pendidikan Indonesia). 
the purpose of education that was also as the purpose of society. In the ancient time, because of the limited demographical factor where the nature and all of the resources within were well preserved, the purpose of education can almost be ensured to include religious aspects. Therefore, it was not impossible if the content of education at that time was characterized by spiritual-humanism such as religion with all dharma, superstitious, arts, literary, konogran, governmental, etc. in line with the mission of those respective communities. Those who had graduated from a certain kind of higher education were then titled as pamget, samget derived from the root word of $\mathrm{V}$ pgat or finish, where in this time (200an) it was termed as mastery (Master MA - MSc, in the level of post graduate). Furthermore, in the time of Majapahit (Java), there was also the term of janggan, a doctoral student who had the title of rural doctor because he or she had taken mandala or shramnanya in the hinterland or villages. After finishing the education, he or she gained other professional title: $\mathrm{Mpu}$, thus he was entitled as pujangga or poet such as Mpu Kanwa, Mpu Shendok, Mpu Triguna, Mpu Sedah, etc. they were all great masters (great poets) in their time.

Within the study of ancient Indonesia, there are interesting data of the existence of experts as of artist (of gold, silver, undahagi, etc.), academician, school teachers or counselors who had written or mastered certain kind of knowledge. They lived alone or in a small group in the jungle or mountain far from society that were usually visited by youngsters, either from nobleman or common people to gain knowledge. By and large, the students (Jw. Cantrik, Islam (Jw) santri), different from other people in villages and cities, craved for knowledge and freedom. However, they were presumably interested in ideologies spread within the trade chains thus at the later time, a certain kind of retreat metamorphosed into pesantren such as ampyaldanta, Surawiti, Bonand and Giri.

Kitab Tantu Pagelaran (early $12^{\text {th }}$ century) that was as old as Pararaton listed a number of different retreats that can be classified by paksa or the number of people within, i.e. based on the type of community or association. Among them are rsi, saiwa, saugata, bhairawa, tyaga, kasturi. The ritual groups along with the sites were defined by Lombard as a form of mandalah who worshipped the founding father or the ancestors.

The implemented system, however, was either individualistic or classical. From the physical source as of the rubble of the facilities, it is known that the education could cover a mass number of people of different social classes. The facilities included sacred places such as Palah (Panataran), mandala, ashrama, that were all scattered within Gunung pananggungan and vihara which had existed since $7^{\text {th }}$ century, such as Sari and Plaosan temples.

From the limited sources and through the juxtaposition of the education system in pesantren in the early periods ( $15^{\text {th }}$ and $16^{\text {th }}$ century), it can be estimated that the teaching learning methods were conducted individually and classically, as what is written in serat Nawaruci, Heti Boek van Bonang or Early Mulem Code Ethics. In the terms of knowledge, based on the sites, the knowledge learned 
and taught comprises the type of pilgrims, meditations, and retreat. Regarding this, besides Nawaruci and Cabolek, there were also Centhini, serat Cabolek and Bhujanggamanik. Among the existing levering is the retreat of knights as of Baladewa in Grojongansewu, Hanuman and Kendalisada, Sakuni in Sokalima, Rsi Bisma in Talkanda, etc.

A certain kind of media was also invented in order for the message of education to be followed by other people or the next generation such as of literary, relief and tutur. The educational board of mandala along with its traditions existed in Indonesia, especially in Java, based on certain data, survived until the next period, i.e in the form of pesantren. The tradition following the development including the physical structure, social, educational system, as well as intellectual practices such as pilgrimage of the higher education students (the poet or doctoral candidate) from one mandala to the other mandala or from one pesantren to the other, and the discussion among academicians that is now usually called as seminar, one of the examples is the visit of Bagus Burham to lumajang, Blambangan, and Bali.

\section{The Purpose of Education}

\section{General goal}

The general goal in the era of ancient Indonesia was based on the life cycles and aims determined by religious lesson, namely to get ke-Ipas-an in the end of life based on the lesson of Hindu-Budha, especially Hindu Siwa. Within the Hindu lesson, since the era of Weda, the life cycle was based on how to get, implement, and get keIpasan based on (religious) knowledge in the end of one's life. The life cycle that can be classified based on age levels and one's responsibilities was as follows:

1. Brahmacarin, the teenage or youth, that is the time to get education

2. Grahasta, the adolescent that is the time to make a family

3. Wanaprastha, about to enter the old period that is the time to get the personal aim

4. Pariwrajaka, or Sanyasin, about to death that is the time to reach the freedom and the unity with the highest element through a certain act.

As the religious life received changes, there were four Vedas (Regveda, Yajurveda, Samaveda, and Atharveda) in the era of Veda that was followed by the era of Brahmana, Upanishad (philosophy), as well as various understanding of religion especially those which pertained to man's life cycles, either micro or macro. The changes then resulted in new theories which were then written in holy book, namely:

Weda, Brahmana, Upanishad (Purana) and Agama. Based on the lesson of Hindu, the four books were for the era of krta, dwapara, trea and kaliyuga. The book was also called as tantra that refers to spreading knowledge. Within tantra, there were explanations on tattwa (reality), mantra, and the rid of the 
binds.

In general, Religion comprised the creation of the nature, nature fusion, and worship towards Gods that was the absolute way to get the power and unity with the highest element. To achieve this, a person should get through three ways of trimarga, namely jnana marga (act the knowledge and the truth of the highest element), bhakti marga (that is gained through caring and the worship towards the highest soul), and karma marga (the way of beating personal intention and go to the God's way). This belief was followed by rsi (retreater). Based on the content of tutur: Siwa Sidhanta, the life goal of rsi was to achieve the freedom of soul by uniting with the highest element. Therefore, most of rsi became cisya (student) in a certain mandala to learn from maharshi. Maharshi, who were practicing the lesson from guru, was also called as mahaguru. Furthermore, their skill in the ritual of yoga as to get kelpasan made them also be called as Mahayogin (compare the title of mahaguru or the great guru in the recent time).

Maharsi in the society of ancient Indonesia were also considered as the source of knowledge; therefore they also got the title of Pujangga. They were often visited by kings or their family, as well as those who wanted to study knowledge in religion. The lesson of $r s i$ was spread among society outside keraton or palace. It was then influenced by another belief in society such as: ruwat, jampi-jampi, etc.

In java, the above pattern then became a basic curriculum for education.

\section{Specific Goal (Basic Competences)}

In line with the condition of cultures in Indonesia around $16^{\text {th }}$ to $15^{\text {th }}$ century which was influenced by the culture of Hindhu - Budha, there was also a transition to Islam during the $15^{\text {th }}$ century. Accordingly, the specific goal of education during the time could not be separated from the existing culture (geis en cultuutgebondenheit) and the highest goal was then to gain a perfect life and the ke-ipas-an in the end of life and a fusion with the highest element or mahatman.

\section{Curriculum}

Based on a certain kinds of Hinduism literary, what had been taught in education within the Hindu time in Indonesia, especially in Java, was suggested to include:

1. The guidelines and the way of doing sacrificial act and religious life including Regveda and Atharvaveda

2. The story of gods, myths, and knowledge on the creation of this world.

3. Various kinds of work fields.

4. Various kinds of prays, chants and mantra within ceremony.

5. Prays for curing sick people, beating spirits, giant, desire, etc. 
6. Brahmana which includes theory, system, and rules made by Brahmana

7. Knowledge about the highest elements and the knowledge to understand it.

8. Knowledge on the way of kelpasan as to unite with God (mahatma, Jiwa Besar) the way of getting it.

9. The way to hail god, ghost and spirits.

\section{Educational Stratas (Levels)}

Based on the final goal of human life, i.e. kelpasan, therefore, the curriculum or teaching materials or the content of the teaching also relates to the achievement of the highest element and the way how to get kelpasan which is mystical or confidential. In line with the pesantren which was considered as the continuation of the educational system of mandala; therefore, the educational levels within Hindu time, as well as within the era of Majapahit was suggested as follows:

1. Basic level, where the lesson was about elementary level of religion lessons such as articles of faith, the five pillars, stories of Prophet, stories within holy book.

2. Knowledge of god (tauhid), worship (fiqih), Arabic, etc.

3. Intermediate level, where the lesson includes analysis of various worshipping, tauhid, language, akhlak or deeds, hadits, tafsir or meaning of al Qur'an, etc.

4. Advanced level, where the lesson was a part of religion

5. Special level, where the lesson was specific such as tasawuf / sufi.

\begin{tabular}{|c|c|c|c|c|}
\hline \multicolumn{3}{|l|}{ Pesantren } & \multicolumn{2}{|l|}{ Mandala } \\
\hline \multirow[t]{2}{*}{ Basic } & Lesson & Student & Lesson & student \\
\hline & $\begin{array}{l}\text { Elementary religious } \\
\text { lesson : stories within } \\
\text { holy book stories about } \\
\text { prophet, } \\
\text { Reading Al-Qur'an, five } \\
\text { pillars, articles of faith }\end{array}$ & Santri & $\begin{array}{l}\text { Story about gods, myths, } \\
\text { legends, the creation of the } \\
\text { nature, spells, ceremony } \\
\text { and tradition }\end{array}$ & Cantrik \\
\hline Intermediate & $\begin{array}{l}\text { Lesson on worships (ushul } \\
\text { fiqih), tauhid, Arabic, tafsir } \\
\text { of al - Quran }\end{array}$ & Santri & $\begin{array}{l}\text { Sacrificial acts based on the } \\
\text { lesson of Reg, Sama, Yajur, } \\
\text { and Atharvaveda. Various } \\
\text { of work field. }\end{array}$ & Cantrik \\
\hline Advanced & $\begin{array}{l}\text { Specific study of worship, } \\
\text { tauhid, philosophy, } \\
\text { tasawuf (tarekat) and } \\
\text { tafsir. }\end{array}$ & Santri & $\begin{array}{l}\text { Theory and system of laws } \\
\text { including governmental rule } \\
\text { canonized by Brahmana, } \\
\text { literary works, etc. } \\
\text { The highest knowledge } \\
\text { of highest element and } \\
\text { knowledge to understand } \\
\text { the freedom way. }\end{array}$ & Janggan \\
\hline $\begin{array}{l}\text { Specific level } \\
\text { (takhasus) }\end{array}$ & $\begin{array}{l}\text { Specific lesson including } \\
\text { sufi / knowledge of } \\
\text { makrifat }\end{array}$ & & $\begin{array}{l}\text { The way to invite god and } \\
\text { the freedom way as well as } \\
\text { the way to get it }\end{array}$ & $\begin{array}{l}\text { Poet / } \\
\text { Maharsi }\end{array}$ \\
\hline
\end{tabular}


The Mandalas was used either as the center of religion and education or the place for literary writing.

\section{Educational Levels}

How is the form of the lesson? Is it individual or classical? It seems to be reflected from the condition of the building of mandala as an independence community and patapan or kasiran to achieve personal goal; therefore, the teaching would be individual and classical or communal.

Individual teaching was in the form of lesson or wejangan (from the teacher to the student), dialogue, and a certain acts should be done by the students, for example: retreat. Classical teaching based on tradition in a pesantren was suggested to be in the form of wejangan containing a number of cantrik and mangguyu and ubwan-ubwan, tapwanan and janggan for the advanced students. The teaching system for the advanced students was conducted individually. Furthermore, the inherited knowledge was also confidential.

NR "Anak mami sang bayusta, ngong-wastoni kita rumangsuka maring garbha ning ulun."

Bm "Atut, Bapa Nawaruci, maka kuwacaa kita, apan agung carira ningong"

NR "Anakku sang Senopati, kawaka siwa rumangsuka, rat bhuwana iki kuwaca rumangsuka ring carira ning ulun. Kita rika apan alit, tan kawaka rumangsuka? Saksana rumangsuk sang Wrkodara.

NR "Anakku sang Bayusuta, parang katingaan denta, anakku sang bhima?

Bm "Apadang nawarang angawang-awang katinggalan ningong"

NR "Aanggapa si tan mongkonoa, apan kita wus angrengo cabda kang utama ning utama, wekas ningtutur kalepasan. Marepa magetan, anakku sang Wrkodara! Paran rupane?

Etc.

\section{Teaching through Musyawarah (Conference) or Discussion}

Teaching through musyawarah (conference) had not been found in every sources of Majapahit era. However, by analyzing the root tradition underlying the spread of the culture in Java from time to time, it will not be impossible if the acts spread continuously in the transition time from Hindu to Islam which was indicated by the appearance of "wali sanga". The way how the format of musawaratan was carried out by the wali can reflect the way how the teaching to musawaratan or conference was carried out. The following is noted from G.W.J. Drewes in An Early Javanese Code of Muslim Ethics:

1b.

"...nika sakatahing para wali, sami apaguneman ing Girigajah ring Gunung kadaton, kang pinagunemaken tingkahing mangarifat. Kang karihin Pangeran ing Bonang, kaping kalih Pangeran ing Majagung, kaping tiga Pangeran ing Cirebon, kaping pat, Pangeran ing Kalijaga, kaping lima she Bentong, kaping nem Molana Maghribi, kaping pitu Sek Lemah bang, kaping 
wolu Pangeran Girigajah ing Gunung Kadaton. Duk Paguneman ing dina jamaat, tanggal ping lima ing wulan Ramelan tahun Wa(w)u.

Kang ndika Pangeran Ratu Ing Girigajah maring para wali sedaya: paneda mami prasanak sadaya, den sami amicara tingkahing mangarifat, den sami mufakat, sampun dados parebatan, den sami amelingi-pnelingan, wong punika den dados sawiji, sampun wonten kumalamar, pangawruhe den sami waspaos ing kakaning Pangeran, den sami waskita.

Angadika pangeran ing Bonang: Tingkahing pangawruh iman, tohid iku ora koniga dening wong alul-mangarifat kang sampun waspada kawruhe ....

WontensikangandikaPangeraning Cirebon:jenengmakhlukmangarifat, lamun wong alul iman kawula lunikikapurbah kareh/sampurnanging mangarifat nora aninggali tinibgalan, nora amuji pimuji ....

Anapon kang andika Sek Lemah Bang: Iya i(ing)sun iku Allah, endi si malih mapan orana manih, saki(ing)sun iki.

Kang Andika Molana Magheribi: Eh...arane puniki?

Kang andika Sek Lemah Bang: Nora amba angrasanijisin malih, punapa sangkane winicara malih, mapan dede jisin kang winicara malih, mapan sami amiyak tetebang, ajana rasa-rumasa, den sami tumeka ing pamanggih.

Kang andika Molana Magheribi: Inggrih leres tuwan punika, anging tanpa raos kapirsa yen tuan ucapaken den anuksme ing tingkah kewala, ampun kapiarso dening wong.

Anapon angandikanira Pangeran ing Girigajah: Pastine kang ran Allah iku kang iki gambuh, anacebaken, talajung amak ngucap sapa weuha ananingsun, yen tan ingsun angranana, iya iku pasti (a)was pisan, ingsun malih ajujuluk prabu Satmata.

Sami angestoken sakatahing para wali sadaya, na(ng)ng kang cinegah pinalang-pinalang ujarira Sek Lemah bang, anging boya idep panyagahe para wali sadaya.

Opportunities in the ancient time were gained through the learning and pilgrimage from one mandala to other mandala as to comprehend the knowledge. This way was still conducted in the transition era between the $19^{\text {th }}$ and $20^{\text {th }}$ century. In the $16^{\text {th }}$ century, the teaching through pilgrimage was described in Serat Bujanggamanik. Bujanggamanik was a Hindu monk from Pajajaran who did the quest to the East Java, visited and lived in various mandala, patapan, and karsia around the valley of mount Pananggungan (Pawitra).

The other source which can also describe the atmosphere of pesantren within the transition period was Cabolek, Centhini, and Babad Ranggawarsita. In Cabolek, it is stated that along the north Java sea shore, there were two big Islamic education centers (Pesantren): Surawesti and Sidaresma. Habib Mustopo identified Surawesti as Surawiti that was known as sacred sites in the back of Kendeng Utara Mountains (3 km southern from Kecamatan Panceng, Sidayu Gresik), while Sidoresmo was located in Surabaya. 
The other form of musawaratan was presumably also conducted by Bhujangga Manik, She Amongraga, Mas Caolang, and Bagus Burham also known as Ranggawarsita.

\section{a. Bujangga Manik}

Bujangga Manik, a Rsi of noble family in Pakuan, went to Jawaguna to comprehend his knowledge. He visited various sacred places, mandala, perguruan or institution and retreat places. His quest was started from Pakuan, through Citarum, Pemali (Brebes), south Pekalongan, Pandanarang, Prawata (Demak), Medang Kamulan (Purwodadi, Grobogan), Daha (Kediri), Majapahit. From Majapahit, Bhujangga Manik went to Penanggungan, Bromo and Blambangan. In that place he took a rest for a year. He then continued his quest to Bali. From Bali he went through southern East Java. He was arrived in palaj (Blitar), in a sacred place where people learn religion and do some worship. Bhujangga Manik lived in Palah quite long and then went home through Gunung Wilis, Gunung Lawu. He passed Central Java through Bobodo (Solo). Finally, by tracing the Java southern sea shore after crossing Segera Anakan, he went to Pakuan.

Those episodes reflect the geographical condition and the description of the visited places and the intellectual works of a teacher and scientist as to find data and purpose.

The illustration of the pilgrimage of Bhujangga Manik, Jayengresi, Mas Caolang and Bagus Burham was depicted in the appendix.

The other figures who tried to widen their knowledge through pilgrimage and discussion with other clerics in certain places in Java were Syek Amongraga and Mas Cabolang as has been told in Serat Centhini.

\section{b. R. Ng. Ranggawarsita}

Ranggawarsita was the last Javanese poet (15 March 1802 - 24 December 1873) as there was no other poet appearing and exceeding him. His child name was R. Bagus Burham, the son of Sunan Pakubuwana IV. His father had actively helped the Diponegoro War (1825-1830) causing a clash with the king and the fall of his carrier. Bagus Burham got his education from Kyai Kasan Besari from Pesantren Tegalsari Ponorogo and through pilgrimage towards many well known institutions, either the institution of Islam Kejawen or Hindu around Central Java, East Java and Bali. One of his work than caused religious conflict around the end of $19^{\text {th }}$ century was Serat Wirid Idyat Jati. Within the work, Ranggawarsita was succeed in integrating concepts of god and the exoteris/creation of Indonesia, Hindu - Budha, and Islam. His rivals then attacked him through the other work such as Dharmo Gandhul of Kyai Kalamwadi, Gotholoco of Prawitaruna an Babad Dhoho of Ki Sumasentika of Daha known as Kediri. Within the conflict, there was a concept offered by Ranggawarsita that was claimed as the lesson from Kyai Kasan Besar (19 $9^{\text {th }}$ century), the student of Sunan Bonang ( $16^{\text {th }}$ century). 
HISTORIA:

International Journal of History Education, Vol. XI, No. 1 (June 2010)

\section{Classical Teaching (Bandonga:Preach/Wejangan)}

The sources from the era of majapahit have not been found yet. However, it was estimated that it was not too different from the lessons delivered by walis who were also known as pandita or monk. One of the teaching forms cited in Het Boek van Bonang is as follows:

"E.Ridjalmitraningsun kabeh! Den sami amirsahaing toetoeringsoen iku! Kalawansapisaningsoenloemampahingara-araiman,soetingalitindakingsoen ika sarta lan idining sih noegrahaning pangeran. Samsampoeningsoen loe mampah ing ara iman, toemindak ingsoen ing ara-ara tawhis.: jata soentingali tindakingsoen ika tan katon: kang katingalan dengn ingsien ika kahaning Alla keawala. Sasampoen ingsoen loemampah ing ara-ara tawhid ingsoen: tingalingsoen kang maring pangeran pon nora ana. Tegese ikoe dening sampoen anoenggal tinggal dadi nir tingalingsoen ika ing tingal toenggal kang tiningal kang sada andoeloe ing pandoelmira.

Mangka aketjap Shaich al-bari: E.Ridjal kadi palajaraning wong arifin (al-arifu) gharaqtu fi bahri ka'I adami, wong arif iku karem sagara ora.

Mankana matoe(r) Ridjal: ja goeroe amba! Kadi peondi sang aiptaning "sagara ora "poenikoe?

(Mangka aketjap Shaich al-bari): E.Ridjal!Sang Siptane ikoe patemoning 'arif kang ora ikoe dening djinaten dadi nir anane, malah kadi doek doeroeng ana mangkana".

\section{Educational facilities}

As to get the description and to understand the villagers around the ancient time, as well as to understand the educational practice conducted in Java and its connection with the central authority, there were some sources of epigraph of sastra kakawin that can be used. Regarding this, sastra kakawin describes the hinterland lives comprising various data of retreat as of: wanaasmara, patapan, paajaran, pangalusan, parhyangan, katyagan. Those places were the place where the retreater did the semedi or isolation for meditation, either individually or communally. Cantrik and female retreater was taught by an old retreater called as dewaguru, kakihyang, hyang atuha, wiku wrddha. In general, the retreats played as one of the educational media in the places well known for its scenary as have been described in kakawin Siswaratrikalpa.

The educational media here refers to rubble, relief and vihara framework which was used as vihara within the $8^{\text {th }}-9^{\text {th }}$ century. The rubble of mandala includes a gate within the valley of a chasm, around 400 meters from pathirtan Blahan. The site was suspected as the dormitory of Raja Airlangga who quitted his position in the end of his ruling and decided to be a retreater as a part of vanaprastha and samyasin that was known as Rsi Gentayu. 
The site has a big gate where the land within the valley can also be lived by some houses, huts, and fields that could fulfill the basic needs of the community of mandala. The life was described by Siwaratrikalpa as follows:

1. Lugha lampah ikanawetan angalor ramya-ng lurah kongkulan. Taman mandala parhyangan pangalusna katyangan ande lengon Thanyagong suku ing gunung-gunung aneka tanduran tut hiring Lwah gong-gong tumedun saking wukin anak tusyangeneb tanduran.

2. Desapweki kunen katungkulon I sor munghwin slewan ning geger Nyasararja tinon hateb rahab I rangkangnyalamuk katruhan Lumlranladen ikang kukus malimunan sampun mamisren tawang Hob ning wandira tang bale kinalakah pinten pagoshyan sada.

3. Kilyenyeki geger-gegr pasawahanyakrep galengnyalaris.

Kubwanyarneb adaanta-danta tirinyakweh galengnyalaris.

Kuntul mor kumeda-kedap leyep adoh mungwing tengah ning rmen Muksamisra lawan limut kadidepanyapan tn katon

4. "sadinnyeki kadewagurwan amunan lwh gong banynyadalem Dwaranyanilihan wisuddha maruhur tan babra purnalaris Tanjun campaka bana naga kusuma mrik mar sekarnyanenden Kapwatut lalayan binanjar alano kumban humun tan pegat

5. Mungwin jronya arja hineduk sksat gelar nin tulis. Lun nin jangha lume ri lamban awilet kamban sugandhawangi Aglar tan sekar in Katanga ri hadepnyapan ruru kaninan Himper dyah masusup-susup geluran ande harsa nin wwan muat

6. Karnah lornya payajnan arsik I natarnyatandes asryahijo Tunkub-tunkub ikaluhur kalamukan de nin himarantayan Sunyanhin pananis nikn hepin asabdanhrik swaranyalaleh Sankarsan kareno masanghyani lawan ghantatri tan pantara.

The free translation is as follows:

1. The quest brought him to the west east, the ravines showed beautiful scenery as we look down, and the gardens, the circular rest houses, statues and retreat place amazed him. Wide field was around, like tier on the slope of the mountain, a big river went down from the hill and water the trees.

2. There was a village that can be seen from the top, right below the feet, at a valley, within the back of a hill. The building was so beautiful; the roof was made of grass covered by pouring rain. A wisp of smoke flew left some traces in the sky. The public hall was covered by a banyan tree, the roof was made of wild sugarcane, there was often discussion held there. 
3. In the west side, there was back of the hill full of rice fields, the bund was clearly steep. The gardens stood side by side, neat, the coconut tree was hidden by mist. The wings of burung kantul sparkling as they fly, there was a wisp of cloud in the far, then they were gone fading in the mist and diseapear.

4. Next to him, there was kadewaguruan near a big deep river. The gate was point to the sky, white and clean, the wall was made of sand and covered the place thoroughly, tanjung, campaka, bana and nagakussuma spread the aroma as the floweres were blooming, the trees stands circling the temple along with the wall, and the bittle continuously buzzed.

5. Inside the wall, there were slender huts; covered by ijuk enau looked like a painting. Bud of jangga bowed through the paga, the bale stood hand to hand, the aroma was very soft. Leaves from katangga spread on the top laid within the wind. The roof was as if the maid put some flowers in their hair.

6. In the north, there were clean neat worship places, green in the middle of dried place. The temple looked so grandeur hazed by mist. Peaceful, only weep of heping.

It was a high sad sound.

The sound of sangkha blew hardly and continuously, along with with the ring of the bell, hailed men to pray.

The depiction of mandala above clearly shows slope of a mountain. But where? In the third verse, there was phrase of : ilatul hiring in wukir lari nikalen umulati ramya nin pasir, anan matra kattunkulan banu nikan jalzadhi kadi mawor lawan lanit (and after he gleefully down the slope there was a beautiful scenery, where there was only rippled of sea water unite with the sky).

Supposing that the sentences of sriwaratrikalpa was ended with northeast as has been stated by Werta Santjaya "rarahen I lanen in wukir patapan leyep, yadi katekaha din lajadhy aparajita (seen by him, hazy hill and the retreat place, if you see the northeast there was sea...) thus it is undoubtedly that the mandala was situated in the slope of Penanggungan or Arjuno ruled by Sri Ai Surapraphawa, the heir of Giridrawangsa, in the end of Majapahit era.

\section{Conclusion}

Along with the spread of Islam in Java (also in Sumatera), the system of mandala continued to exist in line with what had been said by Pararaton (1613). Moreover, babad Tanah Djawi also informed that Jaka Tingkir known as Mas Karebet who then became Sultan Adiwijaya of Pajang (1546-1582) spent his young age to learn from one retreat to another. Educational system was in the form of student-teacher, living in the dormitory (pondok or hut), as the part of independent and isolated community. It is strongly believed that at the time before Islam, there was no educational system which then metamorphosed into pesantren. 
Regarding this, some pedagogic states that were apart from the terminological definition, it is undoubtedly accepted that based on the physical structure of the ashrama and the system, pesantren was developed from education on Hindu or mandala. Addition to its educational system of teacher-student, ashrama system, there were some other features, namely its location which was far outside the city, the lesson given that was about religion, the teacher who also got fixed salary, respect to the teacher and the tradition of pilgrimage as well as discussion about knowledge between junior and senior, especially in terms of confidential knowledge, such as makrifat.

One of the pesantrens that existed in the middle of the $19^{\text {th }}$ century was pesantren Tegalsari in Ponorogo under the control of kiai Kasan Besari. The ancestosr of the Kyai in the middle of the $18^{\text {th }}$ century also gained triman from pakubuwanan III as they had defended Pakubuwana II when he had to refuge to Ponorogo because of Chinese riot in Kartasura in 1742. The pesantren then became the place where the last Javanese Pujangga R. Ng. Ranggawarsita studied.

\section{REFERENCES}

Arismunandar, A. (1994). Kegiatan Keagamaan di PAWITRA : Gunung Suci di Jawa Timur Abad 14-15 M. FSUI.

Andjar, A. (1982). Misteri Pujangga Ranggawarsito. Mengapa?. Solo.

Brandes, J.L.A., 1913. "Oud-Javaansche Oorkonden Naglaten Transcripties" dalam Verhendelingen van het Bataviaasch Genootschap van kunsten en Wetenscappen Deel LX Eerste stuk, Albrecht \& Co.,/Batavia: M. Nijhoff/sGravenhage.

Brandes, J.L.A., (1920). Pararton (Ken Arok) Het boek der kongen van Tumavel en Majapahit”. Verhendelingen van het Bataviaasch Genootschap van Kunsten en Wetenscappen Deel LXII. Martinus Nijhoff/'s-Gravnhage: Albrecht \& Co.,/ Batavia.

Bosch, F.D.K,.(1974).Masalah Penyebaran Kebudayaan Hidnu di Kepulauan Indonesia. Jakarta: Bharata

Casparis, J.G. (1958). de" Short inscription from Tjandi Plaosan Lor" dalam Berita Dinas Purbakala : Bullerin of the Archeological Service of The Republic of Indonesia No.14. Jakarta.

Cohenstuart, A.B., (1875). Kawi oorkonden Facsimile, voor rekening van bataviaasch Genotschap van Kunsten en Wetenshappen. E.J.De Brill, Leiden.

Drewes, G.W.J. (1978). An Early Javanese Code of Muslim Ethics. Martinus Nijhoff.

Jones, A.M.B. (1984) "Early Tenth Century Java from Inscriptions" dalam Verhandelingenvan het KoningklijkInstitutvoorTaal,-Land-envolkenkunde. Foris Publications, Dordrecht-Holland/ Cinnaminson-USA.

Kasidi, A. (2004). Kepurbakalaan Sunan Giri.Unesa University Press. 
Lombard, D. (1996). Nusa Jawa: Silang Budaya: Jaringan Asia 2. Jakarta: Gramedia.

Mardiwarsito, L. (1978). Kamus Jawa Kuno Indonesia. Flores. Nusa Indah.

Naerssen, J.H. (1974). van, Saptopapatti, Studi Club Mahasiswa Jurusan Sejarah. FKIS-IKIP Malang.

Pigeaud, Th. (1960). Java in the 14th Centruty. A Study in Cultural Histroy I-V. Martinus Nijhoff. The Hague

Prijohoetomo. (1934). Nawaruci, Inleiding, middeljavaanshe prozateksi, vertailing vergeleken met de Bimasoetji in Oud-Javaasch Metrum. Academisch Proefschrift aan de rijksuniversiteit te Utrecht.

Slametmuljana. (1965). Menuju Puncak Kemegahan (Sejarah Kerajaan Majapahit). Balai Pustaka. Jakarta.

Slametmuljana. (1967). Perundang-Undangan majapahit. Djakarta: Bharata

Schrieke. (1916)., Het Boek van Bonang, Poefschrift aan de Rijkauniversiteit te Leiden.

Steenbink, K.A.,Pesantren Madrasah Sekolah Pendidikan Islam dan Kurun Moderen, LP3ES, Jakarta, 1994.

Teeuw, A., Ed., Siswaratrikalpa of Mpu Tanakung, An Old Javanese Poem, its Indian Souce and Balinese Illustrations, Martinus Nijhoff, The Hague, 1969. Wojowarsito, S., Sedjarah Kebudajaan Indonesia : Indian Zaman Purbakala, Siliwangi, Djakarta. 1953.

Zamakhsyari Dhoffer, Tradisi Pesantren, Studi Tentang pandangan Hidup Kyai, LP3ES, Jakarta, 1982.

Zoedmulder, P.J., Old Javanese-English Dictionary I-II, Martinus Nijhoff, 's-gravenhage, 1982., Kalangwan, Sastra Jawa Kuno Selayang Pandang, Penerbit Djambatan, Jakarta, 1983. 